\title{
A Numerical Experiment of the Atmospheric Radiation
}

\author{
By K. Takahashi*, A. Katayama** and T. Asakura* \\ Japan Meteorological Agency*, Meteorological Research Institute ${ }^{* *}$ \\ (Manuscript received 8 August 1960)
}

\begin{abstract}
Net flux of long wave radiation and its divergence in the model atmospheres were calculated numerically and tabulated. Glancing over the tables, it was found that the change of the net flux and its divergence due to the change of water vapour amount was comparatively small while the change by cloudiness was large. The values of cooling rate of the atmosphere calculated by the present authors were compared with London's calculations. It was found that both values agreed roughly in middle troposphere, but that there were differences near the earth's surface and the upper stratosphere.
\end{abstract}

\section{Introduction}

The role of atmospheric radiation is very important in the atmospheric heat budget. The analytical study of the atmospheric radiation, however, is quite difficult owing to the complicated effects of various factors, such as temperature distribution, cloud and water vapour. In such cases, empirical rules derived from the results of numerical calculations for various models are useful as a method of research. Phillips ${ }^{1)}$ has made a research on the general circulation of the atmosphere by numerical calculations under some simplified assumptions. He called such the method of the research a numerical experiment. Similar method may be applicable to the present problem.

Of course, many investigations on the atmospheric heat budget have been made already by many authors, such as, Ångström²), Baur and Phillips $^{3)}$, Simpson ${ }^{4)}$, Houghton ${ }^{5)}$, London $^{6)}$ and others. Their purposes of the calculation, however, were to found the heat budget in the real atmosphere. As the state of the real atmosphere is complex, it was not easy to inspect the effects of various factors on the radiation amount. Their researches should be called the case studies. In the present paper, the long wave radiation flux and its convergence will be calculated numerically for simplified atmospheres. And the general characters of radiation amount will be discussed.

\section{Method of calculations and the adopted model atmosphere}

Scheme of the numerical calculations of radiation flux and its convergence has been planned by Katayama. Here only a rough sketch of the method of calculations will be shown. Details of the calculations will be referred to his paper. The principle of the present calculation is equivalent to the graphical calculation using Yamamoto's radiation chart including the correction of $\mathrm{CO}_{2}$. The radiation is calculated numerically for the model atmosphere divided by 20 layers of equal pressure difference, assuming that the surface pressure is $1000 \mathrm{mb}$. The calculations were done by the I.B.M. 704 electronic computer prepared in Japan Meteorological Agency.

The model atmosphere adopted in the present calculation is determined by the following assumptions.

1) Lapse rate in the troposphere is constant.

2) The stratosphere is isothermal and its temperature is decided by the surface temperature. The relationship between them is obtained by the climatological data.

3) The difference between atmospheric temperature and dew point is uniform. This is roughly equivalent to the relation that the relative humidity is uniform. 
4) The cloud layer is assumed to be a The numerical values of the model atmosblack body. Cloud height and cloud thick- phere determined by the above assumptions ness are decided by the surface temperature." are shown in Table 1 and in Fig. 1.

Table 1. Model atmosphere

\begin{tabular}{|c|c|c|c|c|c|c|c|c|c|}
\hline \multicolumn{2}{|c|}{$\begin{array}{c}\begin{array}{c}\text { Surface } \\
\text { temperature }\end{array} \\
\text { Pressure } \\
\end{array}$} & -40 & -30 & -20 & -10 & 0 & 10 & 20 & $30^{\circ} \mathrm{C}$ \\
\hline \multicolumn{2}{|c|}{$1000 \mathrm{mb}$} & -40.0 & -30.0 & -20.0 & -10.0 & 0.0 & 10.0 & 20.0 & $30.0^{\circ} \mathrm{C}$ \\
\hline \multicolumn{2}{|l|}{900} & -38.4 & -31.6 & -23.0 & -14.3 & -4.6 & 4.2 & 14.0 & 23.3 \\
\hline \multicolumn{2}{|l|}{800} & -37.0 & -33.0 & -26.4 & -19.2 & -9.6 & -1.7 & 7.3 & 16.5 \\
\hline \multicolumn{2}{|l|}{700} & -35.1 & -34.7 & -30.0 & -24.2 & -14.8 & -7.8 & 0.5 & 9.5 \\
\hline \multicolumn{2}{|l|}{600} & -34.0 & -36.5 & -34.0 & -30.0 & -20.5 & -14.5 & -6.6 & 1.3 \\
\hline \multicolumn{2}{|l|}{500} & -34.0 & -38.0 & -38.0 & -36.0 & -27.5 & -22.3 & -15.0 & -8.0 \\
\hline \multicolumn{2}{|l|}{400} & -34.0 & -38.0 & -41.0 & -43.0 & -36.0 & -32.0 & -25.9 & -19.2 \\
\hline \multicolumn{2}{|l|}{300} & -34.0 & -38.0 & -41.0 & -45.0 & -46.2 & -44.2 & -37.7 & -31.7 \\
\hline \multicolumn{2}{|l|}{200} & -34.0 & -38.0 & -41.0 & -45.0 & -51.0 & -56.5 & -54.0 & -49.8 \\
\hline \multicolumn{2}{|l|}{100} & -34.0 & -38.0 & -41.0 & -45.0 & -51.0 & -58.0 & -66.0 & -75.0 \\
\hline \multicolumn{2}{|l|}{0} & -34.0 & -38.0 & -41.0 & -45.0 & -51.0 & -58.0 & -66.0 & -75.0 \\
\hline \multicolumn{2}{|l|}{ Clouds } & & & & & & & & \\
\hline Low & $\begin{array}{l}\text { Base } \\
\text { Top }\end{array}$ & $\begin{array}{l}960 \\
920 \\
\end{array}$ & $\begin{array}{l}950 \\
900\end{array}$ & $\begin{array}{l}940 \\
870\end{array}$ & $\begin{array}{l}930 \\
850 \\
\end{array}$ & $\begin{array}{l}920 \\
850\end{array}$ & $\begin{array}{l}910 \\
810\end{array}$ & $\begin{array}{l}900 \\
800\end{array}$ & $\begin{array}{l}900 \mathrm{mb} \\
800\end{array}$ \\
\hline Middle & $\begin{array}{l}\text { Base } \\
\text { Top }\end{array}$ & $\begin{array}{l}850 \\
810\end{array}$ & $\begin{array}{l}810 \\
760 \\
\end{array}$ & $\begin{array}{l}770 \\
700\end{array}$ & $\begin{array}{l}740 \\
660\end{array}$ & $\begin{array}{l}700 \\
610 \\
\end{array}$ & $\begin{array}{l}670 \\
570 \\
\end{array}$ & $\begin{array}{l}630 \\
530 \\
\end{array}$ & $\begin{array}{l}600 \\
500 \\
\end{array}$ \\
\hline High & $\begin{array}{l}\text { Base } \\
\text { Top }\end{array}$ & $\begin{array}{l}670 \\
650\end{array}$ & $\begin{array}{l}580 \\
550\end{array}$ & $\begin{array}{l}480 \\
450\end{array}$ & $\begin{array}{l}380 \\
350\end{array}$ & $\begin{array}{l}290 \\
250 \\
\end{array}$ & $\begin{array}{l}210 \\
170\end{array}$ & $\begin{array}{l}170 \\
120 \\
\end{array}$ & $\begin{array}{l}150 \\
100 \\
\end{array}$ \\
\hline
\end{tabular}

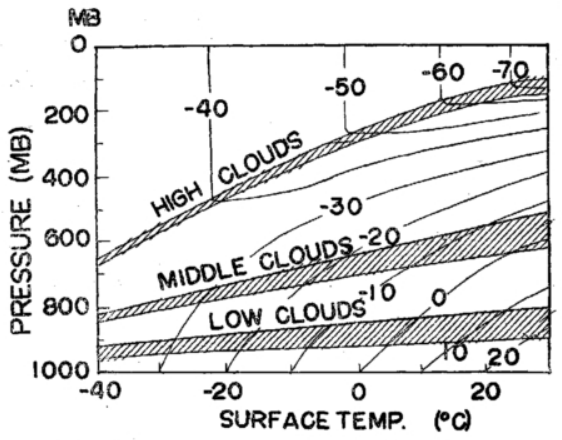

Fig. 1. Model atmosphere, vertical distribution of air temperature and clouds

\section{Effective radiation flux at the earth's surface}

In the following, the results of the calculations will be explained. At first, the effective radiation flux at the surface will be shown in Table 2, for various surface temperatures, dew-point depressions (the difference between air temperature and dew point) and clouds. Glancing over the table, the following characters are found.
Table 2. Radiation flux at the earth's surface No cloud

\begin{tabular}{c|ccccc}
\hline Dew point depression & 0 & 5 & 10 & 15 & $20^{\circ} \mathrm{C}$ \\
\hline $30^{\circ} \mathrm{C}$ & 167 & 190 & 218 & 238 & 264 \\
20 & 177 & 199 & 222 & 246 & 271 \\
10 & 186 & 206 & 228 & 250 & 273 \\
0 & 183 & 202 & 222 & 242 & 263 \\
-10 & 183 & 209 & 219 & 238 & 258 \\
-20 & 168 & 184 & 201 & 219 & 238 \\
-30 & 144 & 158 & 175 & 191 & 207 \\
-40 & 102 & 114 & 129 & 144 & 158 \\
\hline
\end{tabular}

Low cloud

\begin{tabular}{c|rrrrr}
\hline Dew point depression & 0 & 5 & 10 & 15 & $20^{\circ} \mathrm{C}$ \\
\hline $30^{\circ} \mathrm{C}$ & 39 & 41 & 42 & 45 & 46 \\
20 & 35 & 36 & 38 & 39 & 41 \\
10 & 30 & 32 & 33 & 34 & 35 \\
0 & 21 & 22 & 23 & 24 & 24 \\
-10 & 17 & 18 & 18 & 19 & 19 \\
-20 & 10 & 10 & 11 & 11 & 11 \\
-30 & 4 & 4 & 4 & 5 & 5 \\
-40 & -3 & -3 & -3 & -3 & -3 \\
\hline
\end{tabular}


Middle cloud

\begin{tabular}{c|rrrrr}
\hline Dew point depression & 0 & 5 & 10 & 15 & $20^{\circ} \mathrm{C}$ \\
\hline $30^{\circ} \mathrm{C}$ & 86 & 94 & 102 & 111 & 120 \\
20 & 80 & 87 & 94 & 101 & 108 \\
10 & 72 & 78 & 83 & 88 & 93 \\
0 & 57 & 61 & 64 & 68 & 72 \\
-10 & 49 & 52 & 54 & 57 & 60 \\
-20 & 31 & 32 & 34 & 35 & 37 \\
-30 & 12 & 13 & 13 & 14 & 14 \\
-40 & -10 & -10 & -11 & -11 & -11 \\
\hline
\end{tabular}

High cloud

\begin{tabular}{c|rrrrr}
\hline Dew point depression & 0 & 5 & 10 & 15 & $20^{\circ} \mathrm{C}$ \\
\cline { 2 - 6 } $30^{\circ} \mathrm{C}$ & 150 & 169 & 188 & 209 & 231 \\
20 & 151 & 168 & 186 & 204 & 222 \\
10 & 148 & 163 & 177 & 192 & 207 \\
0 & 123 & 134 & 144 & 155 & 166 \\
-10 & 101 & 108 & 116 & 123 & 131 \\
-20 & 62 & 66 & 70 & 74 & 78 \\
-30 & 25 & 26 & 27 & 29 & 30 \\
-40 & -20 & -21 & -22 & -23 & -28 \\
\hline
\end{tabular}

1) The change of the amount of the effective radiation is comparatively small for the change of the surface temperature. Weak maximum is found in the region between $10^{\circ} \mathrm{C}$ and $-10^{\circ} \mathrm{C}$ for the cloudless sky. As the radiation from the earth's surface decreases with the decrease of the surface temperature, these results seem to be curious. But it is explained by the increase of the radiation from the atmosphere due to the increase of vapour.

The effective radiation from the surface has been studied already by many authors. Brunt ${ }^{7}$ ) derived an empirical formula as follows :

$$
R=\sigma T^{4}(0.474-0.065 \sqrt{e})
$$

where $R$ is the effective radiation for clear sky, $\sigma$ the Stefan-Boltzmann constant, $T$ the temperature and $e$ the water vapour pressure in the air.

Two values of the radiation flux, one calculated from the above empirical formula and the other obtained by the present calculation, will be shown in Table 3 .
Table 3. Effective radiation from the surface for clear sky

\begin{tabular}{c|rr|rr|rr}
$\begin{array}{r}\text { Dew point } \\
\text { depres. }\end{array}$ & \multicolumn{2}{|c|}{0} & \multicolumn{2}{c|}{10} & \multicolumn{2}{c}{$20^{\circ} \mathrm{C}$} \\
$\begin{array}{c}\text { Surface } \\
\text { temp. }\end{array}$ & Emp. & Num. & Emp. & Num. & Emp. Num. \\
\hline $30^{\circ} \mathrm{C}$ & 50 & 167 & 157 & 218 & 246 & 264 \\
10 & 189 & 186 & 238 & 228 & 278 & 273 \\
-10 & 207 & 183 & 233 & 219 & 246 & 258 \\
-30 & 180 & 144 & 187 & 175 & 191 & 207 \\
\hline
\end{tabular}

Here Emp. expresses the values calculated by Eq. (1) and Num. that obtained by the present calculation. Both values agree comparatively well except at high temperature.

The agreement shows that the present calculations are reasonable. Disagreement at high temperature seems to be due to the inadequacy of the Brunt's formula at high temperature.

2) The effective radiation increases with the decrease of dew point, though its increase is small.

3) The effect of clouds is large. For example, when low clouds cover the sky, the effective radiation becomes 16 percent of the amount for clear sky, provided the surface temperature is $10^{\circ} \mathrm{C}$. Of course, such a percentage depends on the surface temperature, but its effect is not large.

The calculated values of the radiation flux are also checked in the following way. The decrease of the effective radiation is estimated by the rate of nocturnal cooling. In Table 4, such a decrease of the effective radiation is shown for various clouds estimated by the present calculation as well as estimated from the nocturnal cooling by Asklöf, Takahashi and Liutershtein ${ }^{8)}$.

Table 4. Percentage of the effective radiation for various sky conditions

\begin{tabular}{l|cccc}
\hline Cloud condition & $\begin{array}{c}\text { No } \\
\text { cloud }\end{array}$ & $\begin{array}{c}\text { High } \\
\text { cloud }\end{array}$ & $\begin{array}{c}\text { Middle } \\
\text { cloud }\end{array}$ & $\begin{array}{c}\text { Low } \\
\text { cloud }\end{array}$ \\
\hline $\begin{array}{l}\text { Numerical } \\
\quad \text { calculation }\end{array}$ & 100 & 78 & 36 & 15 \\
Asklöf & 100 & 80 & 25 & 14 \\
Takahashi & 100 & 80 & 30 & 15 \\
$\begin{array}{l}\text { Liutershtein \& } \\
\quad \text { Chuduovskii }\end{array}$ & 100 & 80 & $40 \sim 30$ & $20 \sim 10$ \\
\hline
\end{tabular}


The percentage of the decrease of the effective radiation obtained by both methods agrees at least in the first approximation. Thus, our calculations are justified.

\section{Effective radiation at the top of the atmosphere}

The effective radiation flux at the top of the atmosphere, that is, the outgoing infrared radiation from the earth's atmosphere is shown in Table 5 , for various surface tem-

Table 5. Radiation flux at the top of the atmosphere (Long wave).

No cloud

\begin{tabular}{c|ccccc}
\hline Dew point depres. & 0 & 5 & 10 & 15 & $20^{\circ} \mathrm{C}$ \\
Surface temp. & & & & \multicolumn{3}{c}{ 1y/day } \\
$30^{\circ} \mathrm{C}$ & 553 & 576 & 600 & 623 & 646 \\
20 & 518 & 540 & 559 & 579 & 598 \\
10 & 484 & 501 & 517 & 533 & 549 \\
0 & 451 & 463 & 476 & 489 & 501 \\
-10 & 419 & 427 & 436 & 445 & 454 \\
-20 & 389 & 394 & 400 & 405 & 410 \\
-30 & 362 & 364 & 366 & 368 & 370 \\
-40 & 346 & 344 & 343 & 342 & 340 \\
\hline
\end{tabular}

Low cloud

\begin{tabular}{c|ccccc}
\hline Dew point depres. & 0 & 5 & 10 & 15 & $20^{\circ} \mathrm{C}$ \\
Surface temp. & & & \multicolumn{3}{r}{ ly/day } \\
$30^{\circ} \mathrm{C}$ & 520 & 539 & 558 & 576 & 594 \\
20 & 484 & 500 & 516 & 531 & 546 \\
10 & 455 & 468 & 480 & 492 & 504 \\
0 & 434 & 444 & 454 & 463 & 472 \\
-10 & 397 & 404 & 411 & 418 & 425 \\
-20 & 379 & 383 & 387 & 391 & 395 \\
-30 & 358 & 359 & 361 & 362 & 364 \\
-40 & 348 & 347 & 346 & 345 & 344 \\
\hline
\end{tabular}

Middle cloud

\begin{tabular}{c|ccccc}
\hline Dew point depres. & 0 & 5 & 10 & 15 & $20^{\circ} \mathrm{C}$ \\
Surface temp. & & & \multicolumn{3}{r}{ ly/day } \\
\cline { 1 - 5 } $30^{\circ} \mathrm{C}$ & 438 & 448 & 459 & 470 & 479 \\
$20^{-}$ & 427 & 436 & 446 & 454 & 462 \\
10 & 402 & 410 & 418 & 426 & 433 \\
0 & 387 & 394 & 401 & 407 & 414 \\
-10 & 366 & 370 & 374 & 378 & 382 \\
-20 & 357 & 360 & 362 & 365 & 367 \\
-30 & 352 & 353 & 354 & 355 & 356 \\
-40 & 353 & 352 & 351 & 351 & 350 \\
\hline
\end{tabular}

High cloud

\begin{tabular}{c|ccccc}
\hline Dew point depres. & 0 & 5 & 10 & 15 & $20^{\circ} \mathrm{C}$ \\
Surface temp. & & & & \multicolumn{1}{r}{ y/day } \\
\cline { 1 - 6 } 30 $\mathrm{C}$ & 171 & 171 & 171 & 171 & 171 \\
20 & 216 & 216 & 216 & 216 & 216 \\
10 & 242 & 242 & 242 & 242 & 242 \\
0 & 279 & 280 & 280 & 281 & 281 \\
-10 & 304 & 304 & 304 & 304 & 304 \\
-20 & 327 & 327 & 327 & 328 & 328 \\
-30 & 341 & 341 & 341 & 342 & 342 \\
-40 & 360 & 360 & 360 & 360 & 360 \\
& & & & & \\
\hline
\end{tabular}

peratures, dew-points and cloud conditions. Glancing over the table, the following charac ters are summarized.

1) The outgoing radiation decreases slightly with the decrease of dew point.

2) The outgoing radiation decreases in most cases with the fall of surface temperature, but in case of high-cloud cover, the outgoing radiation increases with the fall of surface temperature.

3) The effect of cloud conditions on the amount of outgoing radiation is less than that on the radiation flux at the surface.

The present table shows that the earth can not be considered as black body for long wave radiation, if we take a surface temperature as an index of the earth's temperature. The amount of outgoing radiation $R$ (ly/day) is expressed roughly by the following empirical formula.

$$
\begin{array}{ll}
R=468+3.5 \theta & \text { no cloud } \\
R=447+2.9 \theta & \text { low cloud } \\
R=403+1.6 & \text { middle cloud }
\end{array}
$$

Here $\theta$ is the surface temperature expressed in centigrade.

If we assume that the earth is black body, the outgoing radiation must be calculated by Stefan-Boltzmann equation $R=\sigma T^{4}$ or approximately by

$$
R=\sigma T_{0}{ }^{4}+4 \sigma T_{0}{ }^{3} \theta=660+10.0 \theta
$$

Thus, the absolute value as well as the change of the amount of outgoing radiation due to the change of surface temperature is much larger than a real atmosphere as shown in Fig. 2. 


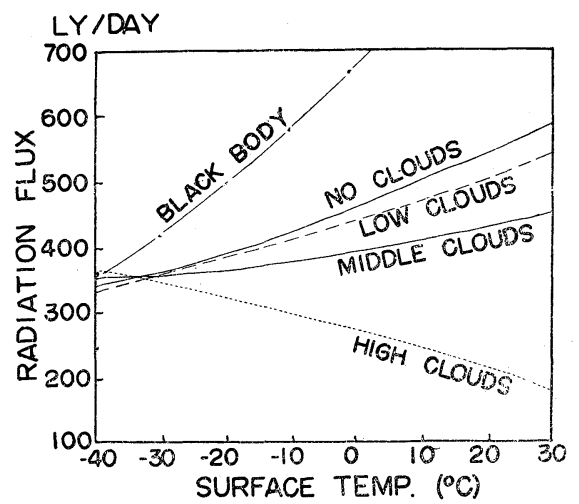

Fig. 2. Radiation flux at the top of the atmosphere

\section{Cooling rate of the whole atmosphere}

The difference of the radiation flux between the top and the bottom of the atmosphere is equal to the mean cooling rate of the whole atmosphere. In Table 6 , this cooling rate of the atmosphere is shown for various surface temperatures, dew-points and clouds.

Table 6. Cooling amount of the whole atmosphere

No cloud

\begin{tabular}{c|ccccc}
\hline Dew point depres. & 0 & 5 & 10 & 15 & $20^{\circ} \mathrm{C}$ \\
Surface temp. & & & & & \\
\hline $30^{\circ} \mathrm{C}$ & 386 & 386 & 382 & 385 & 380 \\
20 & 341 & 341 & 337 & 333 & 327 \\
10 & 298 & 295 & 289 & 283 & 276 \\
0 & 268 & 262 & 254 & 247 & 238 \\
-10 & 236 & 218 & 217 & 207 & 196 \\
-20 & 221 & 210 & 199 & 186 & 172 \\
-30 & 218 & 206 & 191 & 177 & 163 \\
-40 & 244 & 230 & 214 & 198 & 182 \\
\hline
\end{tabular}

Low cloud

\begin{tabular}{c|ccccc}
\hline Dew point depres. & 0 & 5 & 10 & 15 & $20^{\circ} \mathrm{C}$ \\
Surface temp. & & & & & ly/day \\
$300^{\circ} \mathrm{C}$ & 481 & 498 & 516 & 531 & 548 \\
20 & 449 & 464 & 478 & 492 & 505 \\
10 & 425 & 436 & 447 & 458 & 469 \\
0 & 413 & 422 & 431 & 439 & 448 \\
-10 & 380 & 386 & 393 & 399 & 406 \\
-20 & 369 & 373 & 376 & 380 & 384 \\
-30 & 354 & 355 & 357 & 357 & 359 \\
-40 & 351 & 350 & 349 & 348 & 347 \\
\hline
\end{tabular}

As we see in Table 6 , the relations between various elements are too complex to express in a simplified equation. The radiation cooling of the atmosphere depends mainly on cloud conditions, while the variations of the cooling caused by variations of dew-points and air temperature are comparatively small. When the sky is covered by no cloud or low cloud, the cooling rate increases as the temperature increases while the reverse relations hold for middle cloud and high cloud. In the following special cases, i.e., when the sky is covered only by high cloud and the atmosphere is dry and at high temperature, warming of the atmosphere is expected.

\section{Cooling rate of the atmosphere}

Next, the cooling rate of each layer of the atmosphere will be examined. In Fig. 3 the cooling rate of every $100 \mathrm{mb}$ thickness of the atmosphere is shown where the ordinate expresses the pressure level and the abscissa the surface temperature.

As the surface temperature is high in low

Middle cloud

\begin{tabular}{c|ccccc}
\hline Dew point depres. & 0 & 5 & 10 & 15 & $20^{\circ} \mathrm{C}$ \\
Surface temp. & & & & & ly/day \\
$30^{\circ} \mathrm{C}$ & 352 & 354 & 357 & 359 & 359 \\
20 & 347 & 359 & 352 & 353 & 354 \\
10 & 330 & 332 & 335 & 338 & 340 \\
0 & 330 & 333 & 337 & 339 & 342 \\
-10 & 317 & 318 & 320 & 321 & 322 \\
-20 & 326 & 328 & 328 & 330 & 330 \\
-30 & 340 & 340 & 341 & 341 & 342 \\
-40 & 363 & 362 & 362 & 362 & 361 \\
\hline
\end{tabular}

High cloud

\begin{tabular}{c|rrrrr}
\hline Dew point depres. & 0 & 5 & 10 & 15 & $20^{\circ} \mathrm{C}$ \\
\hline Surface temp. & & & & & \\
\hline $30^{\circ} \mathrm{C}$ & 21 & 2 & -16 & -38 & -60 \\
20 & 65 & 48 & 30 & 12 & -6 \\
10 & 94 & 79 & 65 & 50 & 35 \\
0 & 156 & 146 & 136 & 123 & 123 \\
-10 & 203 & 196 & 188 & 181 & 163 \\
-20 & 265 & 261 & 257 & 254 & 250 \\
-30 & 336 & 315 & 314 & 313 & 312 \\
-40 & 380 & 381 & 382 & 383 & 388 \\
\hline
\end{tabular}




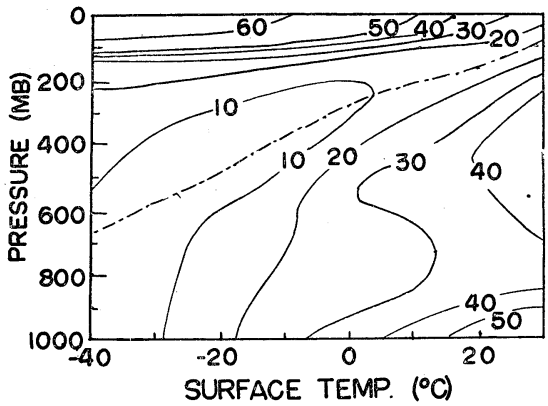

Fig. 3a. Cooling rate of the atmosphere for clear sky (ly/day $100 \mathrm{mb}$ )

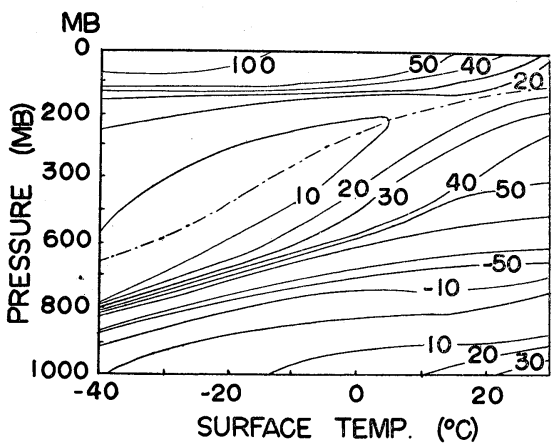

Fig. 3b. Cooling rate of the atmosphere with middle clouds (ly/day $100 \mathrm{mb}$ )

latitude and low in high latitude, Fig. 3 is equivalent to the vertical south-north cross section of the cooling rate of the earth's atmosphere as shown in London's paper. Comparing both Figures, we find many resemblances, for instance, the cooling rate of about $1 \sim 2{ }^{\circ} \mathrm{C}$ per day and the excess of cooling in middle troposphere. The present figures, however, show large cooling near the surface and in the upper stratosphere and the minimum cooling near the tropopause. These points can not be found in London's Figure.

Of course, the present results would not be applicable to an upper stratosphere, because the state of that region is too simplified in the present calculation and the present method based on radiation chart is inadequate for an precise calculation in the stratosphere. Our qualitative results, however, may be considered to be better in a finer structure of radiative cooling than London's results which were calculated graphically, hence his results may be not enough to show such details.

It will be worth to notice that the maxi-

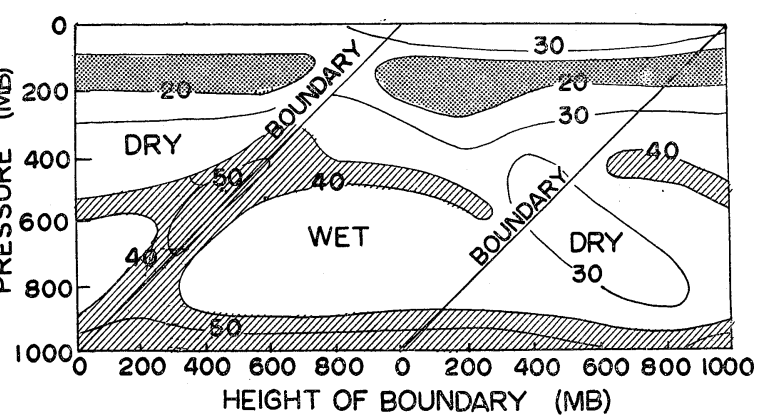

Fig. 4. Cooling rate of the atmosphere composed of dry and wet layers (ly/day $100 \mathrm{mb}$ )

mum cooling rate in the middle troposphere is much distinct in London's Figure. This discrepancy is explained by the difference of the vertical humidity distribution between our model atmosphere and the atmosphere adopted by London. To confirm this point, the following trial is made. Assuming that the atmosphere is composed of two layers, viz., one is saturated air and the other is dry air whose dew point depression is $10^{\circ} \mathrm{C}$, the cooling rate is calculated. The results of the calculation are shown in Figure 4, where the ordinate expresses the height in pressure level of the boundary between wet and dry airs.

When upper layer is dry and lower layer is wet, the cooling rate is large near the boundary between the both layers. While, when upper layer is wet and lower layer is dry, the cooling rate decreases near the boundary.

As the relative humidity decreases generally in upper layer of the atmosphere, one of the reason of the distinct cooling in middle atmosphere may be attributable to the nature of humidity distribution in the atmosphere.

Lastly, the distribution of the model atmosphere, assuming the following amount of cloudiness after London, is calculated as shown in Fig. 5.

\begin{tabular}{l|rrrrrrr}
\hline \multicolumn{1}{c|}{ Temp. } & -30 & -20 & -10 & 0 & 10 & 20 & $30^{\circ} \mathrm{C}$ \\
Cloud & & & & & & & $\%$ \\
Low cloud & 30 & 32 & 33 & 30 & 30 & 23 & $27^{\%}$ \\
Middle cloud & 12 & 13 & 13 & 12 & 12 & 11 & 11 \\
High cloud & 7 & 8 & 9 & 11 & 11 & 11 & 11 \\
\hline
\end{tabular}




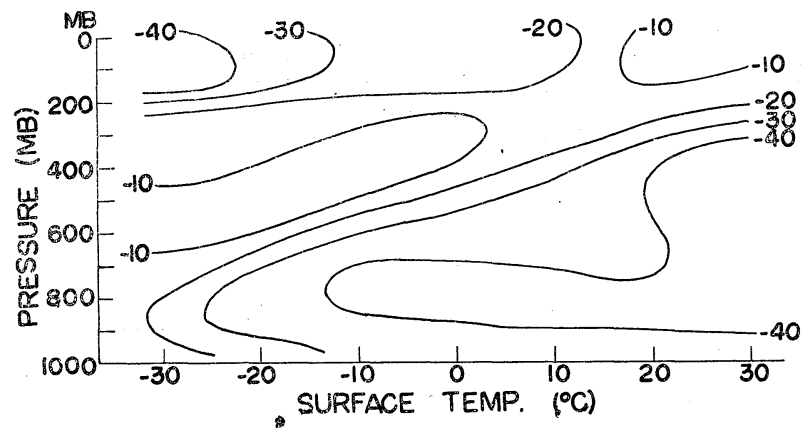

Fig. 5. Cooling rate of the average atmosphere

This is the better approximation to the climatological state of the real atmosphere. By comparing Fig. 3 and 5, we find that clouds shield the outgoing radiation near the earth's surface and the maximum cooling rate near the surface for the clear sky disappears. On the other hand, the maximum cooling rate in the middle troposphere becomes more distinct than in case of clear sky. The height of maximum cooling layer is nearly equal to the average height of middle and low clouds. These results are in good accordance with those obtained by London.

\section{Conclusion}

Here only the numerical values of radiation flux and its divergence are shown briefly. These tables may be helpful for the research of heat budget in the atmosphere. For instance, it is derived that the variation of the surface temperature due to the change of solar radiation is magnified owing to the existence of vapour amount, if we assume radiation equilibrium.

\section{References}

1. Phillips, N., 1956: The general circulation of the atmosphere: A numerical experiment. Quart. Journ. Roy. Met. Soc., 82, 123-164.

2. Ångström, A., 1926 : Energiezufuhr und Temperature auf verschiedenen Breitengraden. Gerl. Beitr. Geophys., 15, 1-13.

3. Baur, F. and H. Phillips, 1934: Der Wärmehaushalt der Lufthülle der Nordhalbkugel, in Januar und Juli und zum Zeiten der Aquinokten und Solstitien. Gerl. Beitr. Geophys., 42, 160-207.

4. Simpson, G. C., 1929: The distribution of terrestrial radiation. Mem. Roy. Met. Soc., 3, 23.

5. Houghton, H. G., 1954: On the annual heat balance of the northern hemisphere. Jour. Met., 11, 1-9.

6. London, J., 1952: Study of the atmospheric heat balance. Journ. Met., 9, 145-151

7. Brunt, D, 1934: Physical and dynamical meteorology, Cambridge.

8. Budyko, M.I., 1958: The heat balance of the earth's surface.

\title{
大気 熱放 射の 数 值 実 験
}

\author{
高橋浩一郎*・片山昭**.朝 倉 正* \\ (気像庁*, 気象研究所**)
}

\begin{abstract}
大気の熱放射についてはすでそ多くの人が研究しているが，ここではモデル的な気温，露点温度，雲の鉛直分布を

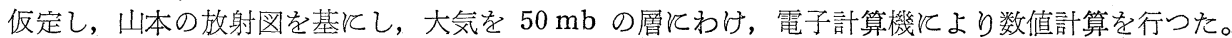

その結果は地表の気温，気温と露点温度の差，雲をパラメーターとして表示した。

この表をみると, 露点温度が多少変化してあ放射の流れや収れんはあまり大きく変らないが，雲の状況は非常に大 きな影響があり，大気熱放射を論ずる場合飞は雲の模樣を正しく推定することが一義的に重要なことがわかる。ま た，熱放射による大気の泠却の模様を調べてみると， ロンドンが計算したように大気の中層に冷却の大きいところが 出るが，それ以外飞あ成層圈の上部，地表付近にも椧却の大きいところが出る。また，地表の気温を大気の気温の目 安とするとき，地表の気温がかなり変化しても大気外への放射量はあまり変化しないことがわかる。
\end{abstract}

